\title{
OBJEKTIIVINEN HERMENEUTIIKKA TAPAUSTUTKIMUKSEN LÄHESTYMISTAPANA
}

Ilmari Rostila: YTT, emeritusprofessori, Tampereen yliopisto

ilmari.rostila@tuni.fi

Janus vol. 27 (3) 2019, 283-298

\section{(J) a II U \&}

Tiivistelmä

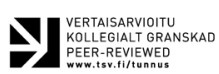

Artikkeli kertoo objektiivisesta hermeneutiikasta tapaustutkimuksen lähestymistapana. Esimerkkinä käytetään sosiaalityöntekijän toiminnan tutkimusta. Objektiivisen hermeneutiikan mukaan (1) tieto perustuu yksilöllisten ja kollektiivisten elämänkäytäntöjen olemassaoloa koskeviin kriiseihin ja (2) inhimillinen toiminta tapahtuu sääntöjen varassa. Lähestymistavan ydin on sekvenssianalyysi, joka tulkitsee elämänkäytännön jättämiä jälkiä (objekteja) valintoina sääntöjen avaamista mahdollisuuksista. Tapauksen rakennetta selvitetään tältä pohjalta objektiivisena merkitysrakenteena, joka on valintojen järjestystä. Sosiaalityöntekijän haastattelua analysoimalla muodostettiin alustava käsitys professionaalisesta toimintatavasta (habitus) kolmevaiheisena merkitysrakenteena. Artikkelin lopuksi verrataan tapauksen rekonstruointia yhtäältä arkikäytännölliseen ja toisaalta ammatilliseen tapauksen ymmärtämiseen ja pohditaan tältä pohjalta tutkimusotteen mahdollisuuksia tukea asiakkaiden elämäntilanteiden selvittämistä yleisesti sosiaalityössä.

Tapaustutkimus ymmärretään perinteisesti tutkimustapana tai tutkimusstrategiana, jonka kohteena on tapahtumakulku tai ilmiö, kuten yksilö, yhteisö tai organisaatio. Kohteesta pyritään tekemään perusteellinen ja tarkkapiirteinen esitys tai kuvaus. Tapaus ymmärretään tällöin tavallisesti yksittäistä tapausta yleisempää problematiikkaa vasten niin, että tutkimus ei ole vain tapauskuvaus, vaan palvelee yleisempää kiinnostusta ja yleistämistä. (Laine ym. 2007.) Objektiivinen hermeneutiikka pitää kiinni tapaustutkimuksen yleistettävyydestä. Se ei hyväksy yleistettävyyden sitomista tilastolliseen edustavuuteen eikä myöskään perinteistä tulkintaa hermeneutiikasta ideografisena, yksittäistapauksiin rajoittuvana tieteenä. Näin objektiivinen hermeneutiikka rikkoo perinteisen metodologisen rajan yhtäältä ymmärtämisen ja selittämisen välillä ja toisaalta ideografisen ja nomoteettisen tutkimuksen välillä. Se näkee ymmärtämistyön kohteen sekä yksittäisenä tapauksena että sosiaalisena tosiasiana yhdistäen ymmärtävän ja selittävän tutkimusotteen. (Süßmann 2016, 119-120.)

Objektiivinen hermeneutiikka on metodologista realismia (ks. tästä, Oevermann 2001, 41), jonka pyrkimys objektiiviseen tietoon ja yleistämiseen perustuu kahteen todellisuutta ja tietämistä koskevaan peruskäsitykseen. Nämä ovat (1) käsitys tiedosta ja sen perustumisesta yksilöllisten ja kollektii- 
visten subjektien eli elämänkäytäntöjen kriiseihin ja (2) inhimillisen toiminnan sääntövälitteisyys ja tästä seuraava merkityksien käsittäminen luonteeltaan prosessuaalisina objektiivisina merkitysrakenteina.

Lisäksi objektiivisuuden tavoittelu perustuu elämänkäytännön jälkien objektiivisuuteen. Tutkimus kohdistuu siten elämänkäytäntöjen ilmauksiin materiaalisen hahmon saaneina jälkinä, toiminnan tuloksina, artefakteina. Tutkimuksen aineistona ovat subjektien toiminnan tuloksena syntyneet objektit. Näitä jälkiä tai objekteja kutsutaan objektiivisessa hermeneutiikassa 'protokolliksi' (vrt. englanninkielinen termi record). Tutkimus ei siten kohdistu suoraan elämänkäytäntöihin, kuten subjektien aikomuksiin, vaan jälkiin, joiden perusteella voidaan selvittää elämänkäytäntöjen objektiivisia latentteja merkitysrakenteita. Nämä merkitysrakenteet ovat luonteeltaan abstrakteja yhteyksiä: "(...) niistä ei voida tehdä havaintoja. Niitä ei voi nähdä, kuulla, haistaa, maistaa tai koskea; niitä voidaan vain lukea" (Oevermann 2014, 39). Ajatus, että tekstin merkitys ylittää sen, mitä puhuja subjektiivisesti tarkoitti, ei ole vieras esimerkiksi etnometodologialle tai ns. Grounded Theory -menetelmälle.

Objektiivinen hermeneutiikka on tapauksia rekonstruoivaa tutkimusta, jossa muodostetaan todellisuudessa toimivia, rakennetta koskevia malleja. Tutkimuksessa pyritään näin soveltamaan 'rekonstruktiologiikkaa', joka eroaa määrällisen tutkimuksen 'subsumtiologiikasta", jossa "ulkoa tuotu" luokittelu asetetaan ikään kuin rasteriksi todellisuuden päälle (Oeverman 2001,
22-23). Määrällisessä ja myös kuvailevassa laadullisessa tutkimuksessa ilmiö liitetään - esimerkiksi koodaamalla johonkin ennalta asetettuun, standardisoituun luokkaan tai käsitteeseen. Ilmiö sulautetaan näin toiseen, asetetaan osaksi suurempaa kokonaisuutta (subsume: include or absorb (something) in something else). Objektiivinen hermeneutiikka pitää tätä malleja muodostavan ja luokittavan tutkimuksen eroa syvällisempänä kuin sosiaalitutkimuksen jakoa määrälliseen ja laadulliseen tutkimukseen. Objektiivisessa hermeneutiikassa rakenne ymmärretään $\mathrm{dy}$ naamisena, siis prosessuaalisena. Myös tässä artikkelissa analysoitava professionaalinen habitus on tällainen dynaaminen rakenne. (Emt..)

Objektiivinen hermeneutiikka korostaa pyrkimystä mahdollisimman oikeaan ja tässä mielessä totuudelliseen tulkintaan, mikä tarkoittaa tapauksen rakennemallin osuvuutta (Oevermann $2013,95)$. Tämä tavoite poikkeaa relativismista useiden oikeiden tulkintojen mahdollisuutena sellaisena kuin se ilmenee esimerkiksi sosiaalisessa konstruktionismissa, diskurssianalyysissä ja postmodernistiseen tietokäsitykseen perustuvassa narratiivisessa tutkimuksessa.

Objektiiviselle hermeneutiikalla on ominaista myös kunnianhimoinen "poikkitieteellisyys". Se käsittää näin itsensä "merkityksien strukturoimaa maailmaa" tutkivien kokemustieteiden yleiseksi metodologiaksi, pyrkien kattamaan sosiaali-, historia- ja kulttuuritutkimuksen tieteenalat. (Oevermann 2013, 71). 
Käsittelen seuraavaksi tiedon, kokemuksen ja merkitysten perustumista elämänkäytäntöjen kriiseihin, minkä jälkeen tarkastelen inhimillisen toiminnan perustumista sääntöihin, toiminnan vaiheittaista luonnetta ja vaiheiden analyysiä eli sekvenssianalyysiä. Havainnollistan sitten sekvenssianalyysiä lähestymistavan metodologisena ytimenä tulkitsemalla kahta lyhyttä haastattelukatkelmaa, joissa sosiaalityöntekijä kertoo työstään mielenterveysongelmaisten asiakkaiden kanssa. Analyysi koskee yleisemmin toiminnan ristiriitaisista vaatimuksista nousevaa työn professionaalista luonnetta. Työ vaatii sekä kokonaisvaltaista henkilökohtaisuutta että roolimuotoisuutta. Työ on yleistetyn tiedon soveltamista, mitä ei voida kuitenkaan tehdä teknisesti. Objektiivinen hermeneutiikka ymmärtää nämä ei-tekniset työn ristiriidat tuntemattoman, ei-määritellyn kohtaamisena ja siten kriisinä, joka haastaa työntekijän muodostamaan itsenäisen toiminnan ja havaitsemisen tavan, jota kutsutaan professionaaliseksi habitukseksi (Oevermann, 1996, 86).

Artikkelin lopuksi pohdin tapauksia rekonstruoivan tutkimuksen antia asiakkaiden elämäntilanteiden analysoinnille sosiaalityössä. Sosiaalityön periaatteet tukevat eri näkökulmista asiakkaiden tilanteiden erityisyyden selvittämistä ja tarpeiden yksilöllistä arviointia (Juhila 2006; Niemelä 2012; Särkelä 2011; Pohjola 2010). Monet tekijät kuitenkin estävät syventymistä asiakkaan ainutkertaiseen tilanteeseen. Niinpä palvelujärjestelmän ja organisaatioiden johtamisen tarpeilla sekä näyttöön perustuvilla käytännöillä on taipumus voimistaa asiakkaiden palvelutarpeiden vakiomuotoista määrittelyä. Selvittämi- sen tulisi olla nopeaa, selkeää, yksiselitteistä ja ehkä jopa mittaavaa. (ks. Pohjola 2012.)

Objektiivinen hermeneutiikka näkee arkikäytännöllisessä, ammatillisessa ja tieteellisessä tapauksen ymmärtämisessä paljon yhtäläisyyksiä. Arkinen, professionaalinen ja tieteellinen ymmärtäminen eivät ole kategorisesti eri asioita, vaan niiden suhde on mielenkiintoisempi. Selvittämisen arkinen, maallikkomainen luonne ei saisi johtaa harhaan. Sekä professionaalisessa selvittämisessä että arkisessa toisen ymmärtämisessä tehdään tulkintaa toisen puolesta. Havainto voi tukea asiakkaiden tilanteiden erityisyyden etsimistä. Myös rekonstruoivalla tapaustutkimuksen lähestymistavalla ja käytännöllisellä selvittämisellä on sosiaalityön koulutuksen ja työnohjauksen kannalta kiinnostavia yhtäläisyyksiä.

\section{ELÄMÄNKÄYTÄNTÖ, TIETO, KOKEMUS, KRIISI JA RUTIINI}

Objektiivinen hermeneutiikka tutkii sosiaalisia muodostumia kohtaloaan koskevia ratkaisuja tekevinä elämänkäytäntöinä. Tällaisia elämänkäytäntöjä ovat yksilöt tai kollektiivit, kuten perheet, yritykset tai muut yhteisöt. Niiden on pakko tehdä ratkaisuja, mikä tarkoittaa kriisejä.Tiedon, kokemuksen ja kriisin kolmiyhteys onkin objektiivisen hermeneutiikan teorian ja metodologian eräänlainen alkusolu. (Garz \& Raven 2017,3.)

Yksinkertaisimman ja perustavimman kriisin aiheuttaa se, että jokin tunnistamaton ilmiö, ei-vielä-määritelty seikka, 
nousee toimijan näköpiiriin. Tällaisia seikkoja ovat kaikki uudet asiat. Ilmiön määrittely, määreen antaminen ilmiölle, on tietämistä. Inhimillinen tieto on siis perustaltaan sitä, että ihminen tunnistaa tuntemattoman, ei-vielä-määritellyn asian tai ilmiön, ja selvittää mikä se on. Ennen tietämistä vallitsee kriisi, koska ihmisen on pakko reagoida tuntemattomaan. Sitä, mitä ihminen ei tiedä, hän ei voi ohittaa. Määrittelemätön uhkaa ihmisen olemassaolon tapaa ja käsitystä itsestä. (Oevermann 2016, 57.)

Yksilöiden ja yhteisöjen kehitys eli muutos perustuu tietämistä koskevien kriisien ratkaisemiseen. Ne saavat näin kokemuksia ja luovat tätä kautta uutta tietoa ja toimintaa. Tästä seuraa myöskin tiedon, kuten käsitteiden, objektiivinen elämänkäytännöllinen merkitys ja pätevyys. (Garz \& Raven 2017, 3-6.) Kriisin ja rutiinin erottaminen tarkoittaa, että todellisuus jakautuu tavallaan kahtia. Todellisuuteen kuuluu aiemmin määriteltyjen ilmiöiden (rutiinien) realiteetti ja ei vielä määritelty eli kriisin mahdollisuus. Työttömyys tai sairaus ovat esimerkkejä toimijan aiemmat tiedolliset ja toiminnalliset rutiinit kyseenalaistavista kriiseistä.

Määreen antaminen ilmiölle on vaiheittainen prosessi, joka osoittaa tiedostamisen kytkeytymisen kieleen. Prosessi alkaa luonteeltaan kriisinomaisen ilmiön havaitsemisesta, jatkuu sen työstämisenä ja päätyy rutiiniksi. Esimerkiksi kun Matti herää yöllä kolahdukseen tms. kovaan ääneen, on Matin löydettävä äänen aiheuttaja. Hän voi palata rutiiniin, eli kömpiä vuoteeseen ja jatkaa uniaan vasta tyydyttävän selityksen löydettyään. (Emt., 4.)
Kokemista ja tietämistä vaiheittaisena kriisinomaisena prosessina selventää Meadin sosiaalipsykologinen teoria persoonasta, johon kuuluu minä ('I") persoonan spontaanina, affektiivisena puolena ja minä ("me") persoonan yhteiskunnallisena puolena. Minä ('I“": "se, mitä kukaan toinen ei ole") vastaa esisosiaalisena ja luovana tahona uuden syntymisestä. Uuden syntymiseen osallistuu kuitenkin myös yhteiskunnallinen minä ("me": "se, mitä muutkin ovat"), joka perustuu toisten ihmisten suhtautumistapojen omaksumiseen. (Emt. 4; Mead 1934.)

Kun henkilö elää keskellä sujuvasti etenevää rutiininomaista toimintaa, käytäntö sujuu elettyjen rutiinien mukaan, eikä spontaanisuutta edustavalla minällä ("I") ole syytä puuttua asioihin (Garz \& Raven 2017, 4-5). Kun rutiinitoiminta keskeytyy, kun vaikkapa Matti herää outoon ääneen, tuntematon (X) saa aikaan jännitystilan, joka laukeaa vasta kun tuntemattomasta on muodostettu tunnettu.

Tietämistä koskevan kriisin ensimmäisessä vaiheessa koetaan siis toiminnallinen ongelma, johon spontaanisuutta ja luovuutta edustava minä ("I") reagoi. Tämä tuottaa alkuun kuvien kaltaiset ja vielä ikään kuin pakenevat määrittelyt. Toisessa vaiheessa kuvista muodostuu työstettävissä olevia kohteita. Käyttäen sosiaalisessa minässä ("me") edustettuina olevia näkökulmia subjekti jäsentää kuvia ajatuksellisesti, siis kielellisenkäsitteellisesti, ja synnyttää tätä kautta uutta tietoa. Kolmannessa, tiedon varmistamisen vaiheessa, subjekti kokeilee tiedon kestävyyttä. Näin uudesta tiedosta muodostuu totuttu rutiini, johon 
elämänkäytäntö turvautuu tulevaisuudessakin. (Emt., 5.)

Kriisiteorian perusteella objektiivinen hermeneutiikka erottaa ihmisen maailmasuhteessa merkitysvälitteisen todellisuuden ja välittömän todellisuuden. Merkitykset kumpuavat välittömän, vielä määrittelemättömän, todellisuuden kohtaamisesta. Ihminen ei voi jättää tuntematonta määrittelemättä, ei voi ohittaa ilmiön tunnistamista. Määrittely synnyttää uutta tietoa. Uusi (ja vanha) tieto ja käsitteet syntyvät siis kokemuksen pohjalta. Tieto ja merkitykset ovat elämänkäytäntöjen ratkaisuja suhteessa välittömään todellisuuteen kriisinä. Tähän perustuu niiden objektiivisuus (vrt. sosiologinen kulttuurintutkimus, Alasuutari 2011, 60). (Oevermann 2016, 46-51.) Tiedon ja merkitysten relativismia vastustaen objektiivinen hermeneutiikka ei pidä tietoa ja merkityksiä, kuten vaikkapa yksilön identiteettiä, suhteellisina sillä perusteella, että ne liittyvät elämänkäytännön näkökulmaan. Elämänkäytännön näkökulmaan liittyessäänkin tieto koskee objektiivista, subjektista riippumatonta "tuntematonta".

Kielitieteellinen semiotiikka perustelee merkitysten ja käsitteiden suhteellisuutta sillä, että merkitykset ja merkit viittaavat aina (vain) toisiinsa. Tämän mukaan: "Minkään käsitteen sisältöä ei määritä jokin kielen tai muiden merkkijärjestelmien ulkopuolinen objekti, vaan muut käsitteet, kaikki ne määreet ja määritelmät, joita termille annetaan. Myöskään mikään näistä määritelmistä ei ole käsitteen varsinainen sisältö tai todellinen olemus (-)" (Alasuutari 2011, 63). Objektiivisen hermeneutiikan näkökulmasta merkitykset kehittyvät, kun elämänkäytäntö kohtaa tuntemattomia ilmiöitä ja määrittelee ne uutta tietoa luoden. Merkitysten maailma ei siten ole pelkästään itseensä viittaava ja sillä tavalla suljettu.

Kriisi objektiivisen hermeneutiikan teorian ja metodologian alkusoluna vastaa ajatusta toiminnan kytkeytymisestä perusteiden ja johtopäätösten merkitykselliseen ketjuun. Se perustelee myöskin kaiken toiminnan näkemistä kolmivaiheisena tapahtumana, jolla on menneisyys, nykyisyys ja tulevaisuus. Seuraavassa avattava sekvenssianalyysi tutkimuksen menetelmänä perustuu näihin ajatuksiin. (Garz \& Raven 2017, 5-6.)

\section{TOIMINNAN SÄÄNTÖPERÄISYYS JA OBJEKTIIVISET MERKITYSRAKENTEET}

Sosiaalisen ja kulttuurisen rakentuminen tapahtuu reaalisessa maailmassa, jossa toimivien subjektien panos perustuu sääntöihin ja näihin liittyvään kompetenssiin. Subjektien panoksille, sille mitä he tekevät, on ominaista yhtäältä sääntöihin perustuva peräkkäisyys ja toisaalta merkitysrakenteisuus. Sosiaalinen toiminta on sääntöjen tuottamaa peräkkäisyyttä tai vaiheittaisuutta, joka toteutuu "algoritmin kaltaisesti rekursiivisen yhtälön mielessä". Jokaisella näennäisesti erillisellä inhimillisellä toiminnalla on vaiheittainen luonne. Jokainen erilliseltä näyttävä teko on vaihe siinä mielessä, että se kytkeytyy - säännön kannalta oikein muotoiltuna - edeltävään toimintaan. Samalla se on vaihe myös siinä mielessä, että se avaa puolestaan tilan sitä seuraavalle siirrolle. Toiminnan kulun jokaisessa vaiheessa, jokaisessa toiminnan paikassa, tehdään 
siten valinta niistä mahdollisuuksista, jotka sääntö tarjoaa valittaviksi ja toisaalta avataan tila sille, miten jatkossa voidaan valita. (Oevermann 2000, 64.)

Elämänkäytännön toteutuminen ja samalla merkitysrakenteen muodostuminen voidaan ymmärtää etenevänä ketjuna.Tästä näkökulmasta yksittäisen, irrallisen teon ajatus on harhaanjohtava, koska jokainen teko pitää aina sisällään palan mennyttä ja palan tulevaa. (Garz \& Raven 2017, 7.)

Toiminnan vaiheiden kautta muodostuvan merkitysrakenteen käsitettä voidaan avata esimerkillä äidin ja lapsen vuorovaikutuksesta. Äidin avun tarjoaminen ja lapsen vastaus siihen (kuten avun hyväksyminen tai torjuminen) avaa kolmannen vaiheen, joka on enemmän kuin mainittu toiminta tai reaktio yksittäisinä toimina. Jos äiti lapsen torjunnan jälkeen esittää esimerkiksi äänekkäämmän vaatimuksen saada auttaa, minkä lapsi ehkä puolestaan torjuu yhä jyrkemmin, kehkeytyy useampien jaksojen kautta merkitysrakenne (esimerkiksi äidin ylihuolehtiva, riippuvuutta ylläpitävä kasvatuskäsitys). Vasta kolmannesta vuorosta lähtien, siis toiminnan ja reaktion tuloksesta lähtien alamme päästä selville toimintajakson muodostaman kokonaisuuden merkityksestä. (Emt., 7.)

Toiminnan vaiheittaisuus muodostaa 'toiminnan ykseyden mallin'. Sen mukaan jokaisessa nykyhetkeä edustavassa jakson kohdassa (jakson kohta 0) toteutuu aina valinta toimintamahdollisuuksista, jotka on avattu sitä edeltävässä jakson kohdassa (jakson kohta -1), ja nykyhetkeä edustavassa jakson kohdassa avataan puolestaan aina tila tuleville rat- kaisuille (jakson kohta +1 ). Toiminnan ykseyden malli tarkoittaa myös pakkoa valita ja tässä mielessä kaiken toiminnan kriisinomaisuutta. Valintapakko koskee myös rutiininomaista toimintaa, jossa valinta on kuitenkin automatisoitunut. (Emt., 7.)

Kaikilla inhimillisillä elämänkäytännöillä, kuten yksilöillä tai perheillä, on toiminnan ykseyteen perustuva merkitysrakenteisuus. Subjektin on valittava, ilman ulospääsyä "jatkuvalla syötöllä". Tätä varten subjektilla pitää olla valintoja ohjaava malli eli rakenne, joka toimii subjektin peräkkäisissä valintatilanteissa. Kriisiteorian mukaisesti rakenne perustuu todellisuuden kohtaamisesta nousevaan materiaaliseen, so. uutta luovaan rationaalisuuteen, eikä muodolliseen rationaalisuuteen sanan tavanomaisessa merkityksessä (mekanistis-deduktiivinen järkeily). (Garz \& Raven 2017, 10.)

Empiirisen tutkimuksen suuntausten lähtökohtana yhteiskuntatieteissä, kulttuurintutkimuksessa ja historiatieteessä on perinteisesti ollut subjektiivisesti tarkoitettu merkitys, jota jäljitetään subjektin asemaan asettuen ("jäljentävä näkökulmaan asettuminen", Oevermann 2016, 63). Toiminnan ykseyden malli näyttää, miten merkitys syntyy sosiaalisessa toiminnassa. Ilmaisun, teon jne. objektiivinen merkitys liittyy aina sääntöön ja se voidaan paljastaa vain suhteessa sääntöön. Se käsitetään sääntöjen avulla tuotettuna. (Oevermann 2001, 28.)

Ajatus ihmisen todellisuutta rakentavan panoksen perustumisesta sosiaalisia tosiasioita algoritmisesti tuottaviin sääntöihin pohjautuu Chomskyn (1969) ja 
Searlen (1971) teorioihin. Chomskyn generatiivinen sääntö viittaa rajalliseen joukkoon sääntöjä, joiden avulla on mahdollista tuottaa loputon määrä erilaisia asiaintiloja. Jalkapallon säännöt ovat esimerkki Searlen konstitutiivisesta säännöstä. Kahdenkymmenen kahden henkilön juokseminen kentällä ei ole vielä jalkapalloa.Vaaditaan (jalkapallon) säännöt. (Garz \& Raven 2017, 10-11.)

Objektiivisessa hermeneutiikassa algoritmiset säännöt tarkoittavat yhtäältä universaaleja tietämisen rakenteita ja kompetensseja ja toisaalta historiallisia, aikaan sidottuja normeja ja sääntöjä. Kulttuurisidonnaisia sääntöjä ovat esimerkiksi tavat ja riitit, joiden puitteissa ratkaistaan konkreettisesti yleinen yhteisöllinen toimintaongelma (kuten kuoleminen). Yleispätevien (universaalien) sääntöjen avulla voidaan esimerkiksi tunnistaa asumiseen käytettyjä tiloja tai pukuja myös vieraissa kulttuureissa tai ymmärtää, että läheisen kuolema on merkittävä asia. Sekä yleispätevien että kulttuurisidonnaisten sääntöjen toimivuus näyttäisi edellyttävän Searlen (1983, 141-159) "taustaksi" ("Background") kutsumaa kykyjen kokonaisuutta. Se viittaa yhtäältä realistiseen ja pragmaattiseen suhteeseen maailmaan ja toisaalta tietoon siitä, miten maailma toimii sekä kykyihin selviytyä maailmassa. Tältä pohjalta kielellisten ilmaisujen merkitys käsitetään yli sen, mitä nimenomaisesti sanotaan. Niinpä ruohoa ei erehdytä leikkaamaan kynsisaksilla. (Jansen 2006, 44.)

Objektiivisessa hermeneutiikassa erotetaan 'tuottamisen parametri' ja 'valitsemisen parametri'. 'Tuottamisen parametri' viittaa yleisesti sääntöihin perustuvaan potentiaaliin. Se sisältää sekä universaalit rakenteet, kuten kielen, kognition ja moraalin että historialliset ja paikalliset normit, säännöt ja arvomallit. Tuottamisen parametriin sisältyvät säännöt avaavat subjektin mahdollisuudet kussakin konkreettisessa valintatilanteessa. Käsite 'valitsemisen parametri' tarkoittaa puolestaan niitä taipumuksia, joiden varassa elämänkäytäntö valitsee avatuista mahdollisuuksista. 'Valitsemisen parametri' sisältää subjektin omaksumat periaatteet, normit ja arvomallit, jotka vaikuttavat tehtyihin valintoihin. Eri tieteenaloilla näitä valitsemisen taipumuksia on tarkasteltu erilaisina muuttujina. Psykologiassa muuttujia ovat motiivit tai persoonallisuuden piirteet, taloustieteissä aineelliset elämänmahdollisuudet ja sosiologiassa esimerkiksi erilaiset arvo-orientaatiot. (Garz \& Raven 2017, 10-11.)

Sekvenssianalyysin eli valintojen vaiheittaisen analyysin keskeinen asema objektiivisessa hermeneutiikassa perustuu edellä todettuun. Koska käytäntö rakentuu teoriamuodostuksen kohteeksi sääntöjärjestelmän välityksellä, pitää säännöt rekonstruoida niiden elävässä prosessuaalisuudessa, siis niiden merkityksellisenä peräkkäisyytenä (jaksollisuutena). Tämä tarkoittaa sääntöjen käyttöä erittelevää tulkintaa, jossa käytetään samoja sääntöjä, jotka tuottavat käytännön. Tulkinnassa nojataan siis jokaisen aikuisen ihmisen intuitiiviseen sääntöjen osaamiseen (sääntökompetenssi). (Garz \& Raven 2017, 9.)

Keskittyminen subjektin valintojen mallin rekonstruointiin erottaa sekvenssianalyysin diskurssianalyysistä, jossa kulttuurin ilmiöitä tutkitaan dis- 
kursseiksi ymmärrettyjen puhetapojen kannalta (Jokinen ym. 1999) ja keskustelunanalyysistä, joka tutkii keskustelun keinoja arkipuheessa ja instituutioiden tuottamisessa (Lindholm ym. 2016). Rakenne subjektin valintojen mallina on myös kovin toisenlainen kuin vaikkapa systeemiteorian käsitys rakenteesta osien ja niiden välisten suhteiden muodostamana kokonaisuutena. (Garz \& Raven 2017, 7 \& 9.)

\section{ANALYYSIN PERIAATTEET JA KÄYTÄNTÖ}

Kuten yleensä tapaustutkimuksessa, myös objektiivisessa hermeneutiikassa tutkimuskysymys määrittää tutkittavan tapauksen ja tutkimusaineiston valinnan. Tutkimuksessa on siis ensin päätettävä mitä tutkitaan ja vasta sitten valittava tutkittava tapaus ja aineisto. Merkitysrakenteita voidaan selvittää järjestelmällisesti ja objektiivisesti, siis tutkittavien hyväksynnästä tai mielipiteestä riippumatta, vain toiminnan jälkien perusteella. Merkitysrakenteiden tulee siis ilmetä materiaalisessa hahmossa ulkoistettuina objekteina ja dokumentoituina jälkinä. (Oevermann 2013, 71.) Objektiivisessa hermeneutiikassa aineisto tarkoittaa periaatteessa mitä tahansa elämänkäytännön toiminnasta jäänyttä pysyvää jälkeä eli 'protokollaa' tai 'tekstiä' (termi 'teksti' viittaa protokollaan merkitysten kantajana) kuten haastattelunauhoituksia, lasten piirustuksia, taideteoksia, romaaneja jne. (Garz \& Raven 2017, 13-14.)

'Protokolla' aineistona sisältää oleellisesti ja nimenomaisesti elämänkäytännön oman kirjauksen, sen oman peukalonjäljen. Tämä korostus erottaa objektiivisen hermeneutiikan aineiston em- piirisessä tutkimuksessa tavanomaisesta havainnon ja havaintoaineiston käsitteestä. Näin termin protokolla merkitys on lähellä historiantutkimuksessa käytetyn lähteen käsitettä (ks. pohdintaa laadullisen empiirisen aineiston ja historiantutkimuksen lähteen suhteesta, Virtanen 2001, 44-46).

Seuraavassa sekvenssianalyysin tekemistä havainnollistetaan tulkitsemalla kahden sosiaalityöntekijän haastattelua ja ammatillista toimintamallia. Käytettävissä olleet haastattelunauhoitukset kuuluvat Anne Ylikosken (2013) tutkimukseen, joka käsittelee sosiaalityötä toimintana mielenterveystyössä. Esimerkit edustavat kahta erilaista organisaatiota työskentelyn ympäristöinä. Ensimmäisen haastattelun työntekijä oli työskennellyt pitkään kunnallisessa sosiaalitoimistossa, edustaen näin kokenutta toimintaa organisaatiossa (ks. toiminnan eroista, emt.). Toinen haastateltava työskenteli psykiatrisessa avohoidossa. Haastateltavia oli ennalta pyydetty kuvaamaan ja pohtimaan kolmea asiakastapausta, jotka sisälsivät mielenterveyden problematiikkaa (emt., 43, 105).

Ammatillista toimintatapaa eli habitusta sosiaalityössä voidaan tutkia haastattelun avulla siinä määrin kuin työntekijä on muodostanut työn ristiriitojen kokemisen pohjalta oman rutiininomaisen toiminnan, havaitsemisen ja ajattelun tapansa. Vastatessaan haastattelukysymyksiin työntekijä ilmaisee tätä tapaansa käsitellä työn yliyksilöllisistä ristiriidoista nousevia haasteita. (Maiwald 2003.) Tämä ammatillinen habitus ilmenee hänen puheessaan, eikä hän voi, esimerkiksi vaikutelmia halli- 
takseen, piilottaa sitä (Goffman, 1956). (Wernet 2014, 235.)

Analyysissa tulee erottaa mahdollisuudet, jotka näyttävät sääntöjen perusteella realistisilta ja valinta, jonka toimija on kyseisessä paikassa tehnyt. Kun on määritelty mahdolliset valinnat, päästään kiinni tehtyyn valintaan, siihen, mitä toimija (tietoisesti ja ei-tietoisesti) teki. Yhden valinnan osalta puhutaan (objektiivisesta) tarkoitusrakenteesta, mistä edetään valintojen ketjua analysoimalla tapauksen (objektiiviseen) merkitysrakenteeseen. (Jansen 2006, 45.)

Tärkeä sekvenssianalyysin periaate on "keinotekoinen naiivius". Tekstiin tulee muodostaa mahdollisimman ennakkoluuloton suhde. Lukutapoja pitää keksiä ennakkoluulottomasti ja kattavasti irtautuen omasta tapausta koskevasta tiedosta. Niinpä sosiaalityöntekijän puheesta ei pidä etsiä esimerkiksi jotain sosiaalityöhön kuuluvaa tapaa puhua, vaan pitää selventää aineistolähtöisesti valinnan mahdollisuuksia ja haastateltavan valintaa. Aikaisempi tieto vaikkapa sosiaalityöstä ei saa suunnata tulkintaa eikä jotain lukutapaa pidä sulkea pois esitiedon perusteella. Analyysissä korostetaan tapauksen ylittävän sosiaalisen ja kielellisen sääntökompetenssin merkitystä (vrt. ns. hermeneuttisen kehän periaate). (Emt., 45-46.)

Tekstin ennakkoluuloton tarkastelu, johon ei hallitsemattomasti sotketa aikaisempaa tietoa, auttaa paljastamaan tapauksen rakennetta sekä selvittämään ratkaisut ja tekstin erityisyyden. Yksityiskohdat, kuten sanavalinta, sanajärjestys, kieliopilliset virheet, toistot jne. ovat tärkeitä. Myös näennäisesti tarkoittamattomat ilmaisut tai virheet nähdään tulkinnallista selitystä vaativina. (Emt., 45.)

Analyysi aloitetaan yleensä tekstin alusta, mikä vastaa prosessuaalista käsitystä merkitysrakenteesta. Tämän jälkeen tekstiä avataan jaksoina, pala palalta, siis "loikkaamatta" edemmäs tekstissä. Osana "keinotekoista naiiviutta" jokaista kohtaa tarkastellaan tietämättä mitä sen jälkeen tapahtuu. (Emt., 46.) Tilan puutteen vuoksi tässä analysoidaan yksityiskohtaisesti vain haastattelun aloitusta (ks. analyysistä enemmän, Rostila 2019):

Haastattelija: Mut aloitetaan nyt vaik siit keisistä yksi. niin tota noiniin (.) Kerro nyt vaik siitä asiakassuhteesta vähän, millai millai se se yhteys, niinko mistä suunnasta se tuli, että ottiko hän itse yhteyttä, vai...

Sosiaalityöntekijä: joo mä oon ottanu ne kolme tähän esille. jos mä otan tän Maijan ekaks.

Sosiaalityöntekijän valintaa voidaan selvittää suhteessa kehotukseen "Mut aloitetaan nyt vaik siit keisistä $\gamma k s i "$. Kehotus passiivimuodossa ottaa aloittamisen puheeksi kollektiivisena tekemisenä ja yhteistoimintana. Englanninkielinen versio keissi vihjaa tähän liittyen tutkimushaastattelun ja asiakastyön yhteyteen. Sosiaalityöntekijä ei kuitenkaan tartu tähän mahdollisuuteen yhteisenä tekemisenä. Tämän jälkeen haastattelija pyytää sosiaalityöntekijää suoraan puhutellen kertomaan asiakassuhteesta, mikä on askel lähemmäs itse työn tekemistä. Työntekijä jättää pyynnön huomiotta. Haastattelija tekee sitten suoran täsmentävän kysymyksen (millai millai se yhteys), mihin työntekijä ei vastaa. Haastattelijan erityyppisten 
avausten epäonnistuttua hän ehdottaa asiakkaan tehneen aloitteen (että ottiko hän itse yhteyttä, vai...).Tähän suljettuun kysymykseen työtekijä voisi vastata kyllä tai ei, mutta ei valitse kumpaakaan vaihtoehtoa.

Kun sosiaalityöntekijä ei ryhtynyt raportointiin ja pidättäytyi muutenkin haastattelijan toiminnallisista avauksista, hänen aloituksensa "joo mä oon ottanu ne kolme tähän esille." voidaan tulkita korostetun omaehtoiseksi tapauksista kertomiseksi. Tätä lausuman merkitystä voidaan selventää kertomuksilla, joihin ilmaisu voisi sopia (Garz \& Raven $2015,148)$. Näin voisi sanoa (1) oppilas, jonka opettaja on pyytänyt tuomaan oppitunnille kolme kasvia tms. kohdetta; (2) pilkkikilpailun osanottaja näyttäessään kolmea kalaa kilpailun tuomarille; (3) taiteilija ostajalle, joka on tullut katsomaan uusia teoksia; (4) taiteilija ateljeessa pistäytyvälle kollegalle tai tutulle, jolle taiteilija on maininnut tauluistaan. Puhujalla on kolme nähtävillä olevaa kohdetta, jotka ovat puhujan aikaansaamia ja jotka toisella osapuolella on oikeus tai muu perusteltu syy nähdä. Lisäksi puhuja on huolehtinut etukäteen esineiden esille panosta (hän sanoo "oon ottanu" eikä "otan").

Sosiaalityöntekijä ei ota tapauksia tarkasteluun sovittuun haastattelutoimintaan kuuluvasti, vaan hän puhuu tapauksista oman käytäntönsä osana. Jatko "jos mä otan tän Maijan ekaks" ilmaisee itsenäistä valintaa ja korostaa tapaustyön tekemistä itsenäisesti ja omaehtoisesti. Työntekijä puhuu tapauksista edellä olevien kertomusten tapaan esineiden kaltaisina, vaikka asiakastapaukset eivät tietenkään todellisuudessa ole esineitä. "Maija" on abstraktio, mutta nimetes- sään tapauksen etunimellä, työntekijä ilmaisee samalla henkilökohtaista suhdetta tähän käsitteelliseen tapausolentoon.

Analysoimalla haastattelua eteenpäin sain selville sosiaalityöntekijän kolmevaiheisen objektiivisen merkitysrakenteen. Edellä selostetussa rakenteen ensimmäisessä vaiheessa työntekijä muodosti "luonnollisen asenteen" ylittävän abstraktin tapaustyön tilan. Tämä tarkoitti neutraalia tapauskohtaisen työn itsenäistä käytäntöä, joka on irti eri osapuolten, kuten työntekijän tai asiakkaan näkökulmista ja intresseistä. Neutraali asenne erittelyn tilana mahdollistaa asiakkaan arkielämää jäsentävien ja teoriapitoistenkin mallien muodostamisen. Asiakkaita voidaan kuitenkin käsitellä tapauksina myös byrokraattisen normilähtöisestä näkökulmasta. Tässä suhteessa rakenteen toinen vaihe on tärkeä. Siinä työntekijä eläytyi asiakkaan tilanteeseen ilmentäen henkilökohtaiseen tuntemiseen perustuvaa paneutumista (vrt. asiakkaan etunimen käyttö edellä). Neutraali työskentely tuli ensin, mutta sen puitteissa korostui asiakkaan näkökulma. Asiakkaan näkökulman tunnistaminen ja kunnioittaminen, joka perustuu työntekijän kiinnostukseen asiakkaan motiiveihin "kokonaisena ihmisenä", avaa professionaalisen, ei byrokraattisen auttamistyön mahdollisuuden. Mahdollisuus toteutui merkitysrakenteen kolmannessa vaiheessa, jossa toimintaa luonnehtii asiakkaan aloitteen odottaminen ja odotteleva varovaisuus suhteessa asiakkaan mahdollisiin ratkaisuihin ja ongelmien määrittelyyn.

Mikäli pyritään kehittämään yleistystä sosiaalityöstä toimintana mielenter- 
veyden kysymyksissä, pitää tulkintaa koetella ja täsmentää käyttäen haastatteluja, jotka edustavat toisenlaisia organisatorisia ympäristöjä, työtyylejä ja työkokemusta. (Garz \& Raven 2015, 151, ks. haastattelujen määrästä ns. saturaatiopisteen kannalta, emt., 147.) Seuraavassa tarkastellaan aivan lyhyttä haastattelukatkelmaa, joka edustaa sosiaalityötä psykiatrisessa avohoidossa. Tapauksista puhuminen aloitettiin siinä seuraavasti:

Haastattelija: Eli kenestäs me ensin nyt puhutaan?

Sosiaalityöntekijä: Semmosesta Karista. Haastattelija: Karista. (.) Joo, minkäs ikänen Kari on?

Sosiaalityöntekijä: Kari on syntynyt kaheksakyt kolme.

Sosiaalityöntekijän ilmaisu "semmosesta" luo etäisyyttä puheen aiheena olevaan henkilöön. Haastattelija kysyy tämän jälkeen Karin ikää. Vastauksessaan sosiaalityöntekijä kertoo asiakkaan syntymävuoden. Syntymävuosi on hoito-organisaation tietojärjestelmään kirjattava fakta ja edustaa lineaarisesti etenevää abstraktia aikaa yhteiskunnassa. Toinen vaihtoehto, asiakkaan iän kertominen, olisi viitannut selvemmin ihmisen elämänkulkuun kokemuksena ja avannut empaattisen näkökulman Karin tilanteeseen. Havainto herättää jatkokysymyksiä neutraalin suhtautumistavan luonteesta. Liittyykö neutraalisuus toimintaan psykiatrisen hoitotiimin jäsenenä eikä itsenäiseen tapaustyön käytäntöön kuten sosiaalitoimiston sosiaalityöntekijällä?

Esimerkit havainnollistavat tulkintaehdotusten testaamista ja täsmentämistä, jossa pyritään välttämään ennenaikaista lukutavan lukitsemista. Vaihtoehtoisia tulkintoja pystytään parhaiten kehittelemään ja korjaamaan tutkijoiden ryhmässä keskustellen niistä 'parhaan argumentin' periaatteen (Habermas) mukaisesti. Objektiivinen hermeneutiikka korostaa näin metodologiseen realismiin kuuluvaa fallibilismia, joka nojaa tapausten rakenteen selvittämisessä koko tiedeyhteisön ja tutkijoiden kollektiiviseen työskentelyyn. (Garz \& Raven 2015, 144.)

\section{AMmATILliSEN, ARKIKÄYTÄNNÖLLISEN JA TIETEELLISEN TAPAUKSEN YMMÄRTÄMISEN SUHTEESTA}

Objektiivinen hermeneutiikka korostaa yksilöiden, perheiden ja yhteisöllisten elämänkäytäntöjen fyysis-psyykkisen ja sosiaalisen hyvinvoinnin perustumista luonnolliseen arkiseen ymmärtämiseen. Yksilöiden ja yhteisöjen on kyettävä tulkitsemaan tilanteensa oikein ja tunnistamaan mahdollisuutensa, jotta pystyisivät tekemään itsenäisiä ja järkeviä päätöksiä. Luonnollinen kyky ymmärtää kehittyy itse asiassa jo varhaislapsuudessa vanhempien tulkitessa lapsen tarkoituksia ja sanallistaessa niitä. (Raven \& Garz 2012, 577.)

Sosiaalityön asiakkaat tarvitsevat elämänkulkunsa kriittisissä pisteissä ammattilaisten apua. Tällöin sosiaalityöntekijöiden on arvioitava asiakkaan itsenäisyyttä tukevien palvelujen tarve (Sosiaalihuoltolain soveltamisopas 2017). Sosiaalityö korostaa asiakkaan tilanteen erityisyyden kokonaisvaltaista selvittämistä (Juhila 2006; Niemelä 2012; Särkelä 2011; Pohjola 2010). 
Selvittämisessä korostetaan luonnollista yhteisymmärrystä asiakkaan kanssa ja käytännön tiedon perusteellista ja avointa muodostamista. Liittyen $\mathrm{Ha}-$ bermasin erotteluun elämismaailman ja systeemimaailman välillä Anneli Pohjola (2010) painottaa sosiaalityön asiakkaan oman arjen ja elämismaailman näkökulmaa suhteessa yhteiskunnan, palvelujärjestelmän ja ammatillisten käytäntöjen luokituksiin ja tyypittelyihin. Asiakasta ei saisi nähdä yksipuolisesti oireiden tai ongelmien kautta, vaikka ongelmat ja tilanteen realiteetit pitää ottaa huomioon käyttäen myös vakiintuneita oirekuvauksia ja luokituksia (adhd-oireisto, masennus jne.). Selvittäminen on siten käsitteellistä ja teoreettista tietoa soveltavaa tasapainoilua, jossa etsitään monipuolista ja kokonaisvaltaista käsitystä ja auttamisen mahdollisuuksia. (Emt., 26, 27, 29, 31-32, 34-35.)

Myös Pauli Niemelän (2012) periaatteet käytännöllisestä tapaustutkimuksesta sosiaalityössä ja Antti Särkelän (2011) edustama asiakkaan toimintarakenteen analysointi palvelevat paikalliseen käyttöyhteyteen rajatun tiedon muodostamista. Erittelyssä on pitkälti kyse asiakkaan tilanteen arkisen ymmärtämisen ja teoreettis-tieteellisten yleistysten intuitiivisesta yhdistämisestä. Tilanteiden erittelyssä muodostetaan yksittäisen asiakkaan tilannetta koskevaa paikallista, ei-yleistettävää tietoa.

Pohjola (2010), Niemelä (2012) ja Särkelä (2011) ovat yhtä mieltä siitä, että asiakkaiden elämäntilanteiden selvittämisessä pitäisi käyttää teoreettisia välineitä ja jäsennyksïa ja tieteellistä tietoa hyvinvoinnin ongelmien tunnistamiseksi, mutta toteavat, ettei tämä yleis- pätevä tieteellinen tieto riitä asiakkaan tilanteen erityisyyden ymmärtämiseksi. Pohjola korostaa selvittämisen haasteena muita voimakkaammin väärien luokittelujen ja leimaavien tyypittelyjen välttämistä.

Sosiaaliseen konstruktionismiin nojaavan Juhilan (2006) lähtökohtana on edellisiä vahvemmin käytäntötiedon ja paikallisen tietämisen rakentaminen asiakkaan kanssa ja tieteellisen tiedon haastaminen tätä kautta. Erityisesti asiakkaiden marginaalisissa asemissa muodostetaan vallitsevista luokittelutavoista ja identiteeteistä poikkeavaa "toista tietoa" (emt., 105, 107). Yleiset ratkaisumallit ja tieteellinen tieto ei tavoita ainutlaatuisia, epävarmuuksien ja arvoristiriitojen täyttämiä tilanteita, vaan tarvitaan yhdessä rakentuvaa paikallista tietämistä. (Emt., 140.) Käytäntötiedon muodostaminen sisältää eettistä harkintaa, neuvottelua oikeasta ja väärästä ja asiakkaan toimijuutta rakentavaa tilanteiden jäsentämistä yhdessä asiakkaan kanssa. (Emt., 113, 245, 212-215.) Objektiivinen hermeneutiikka korostaa edellisiä lähestymistapoja vahvemmin arkiymmärryksen, professionaalisen ymmärtämisen ja tieteellisen tapauksen ymmärtämisen limittymistä ja keskinäistä sukulaisuutta, joka perustuu näille toiminnan lajeille yhteiseen luonnolliseen kykyyn ymmärtää.

Toisen osapuolen ymmärtäminen perustuu sekä tavallisessa arjessa että professionaalisessa auttamisessa toisen ihmisen puolesta tehtyyn tulkintaan tämän tilanteesta. Toisen ihmisen toiminnan ja ilmausten merkitystä ymmärretään näin tekemällä kokeilevia oletuksia ilmausten merkityksestä ja testaamalla oletusten pätevyyttä. Puheen merkitys 
avautuu olettamalla sille merkitys, jota sitten koetellaan vuorovaikutuksen jatkuessa. Mikäli oletus ei toimi, pyritään muodostamaan uusi oletus (ks. aivotutkimuksen näkökulmasta, Raven \& Garz 2012, 577). (Koring 1997, 136.) Nojaten tähän kummankin osapuolen luonnolliseen kykyyn ymmärtää asiakkaan elämäntapahtumia tulkitaan intuitiivisesti esimerkiksi osana asiakkaan elämänkulkua. (Emt.)

Samalla professionaalinen ymmärtäminen on silta tieteellisen tapauksen ymmärtämisen ja arkisen ymmärtämisen välillä. Professionaalisessa ymmärtämisessä käytetään (myös) tieteellisestä lähestymistavasta peräisin olevaa tulkintakykyä. Profession toimiminen siltana tarkoittaa siten tieteelliseen abstrahointiin (= tilanteesta irrottautuva) perustuvan yleispätevän tiedon (formaali rationaalisuus) ja kriisitilanteessa syntyvän tilannesidonnaisen järkevyyden (materiaalinen rationaalisuus) yhdistämistä. (Raven \& Garz 2012.) Tutkimusesimerkin tapaustyön käytäntö ilmensi tätä yhteiskunnan, tieteellisen tiedon ja asiakkaan autenttisen näkökulman suhteuttamista, joka vaatii epäsovinnaista eli postkonventionaalista moraalia ( $\mathrm{Zi}$ zek 2012, ks. sosiaalityöstä moraalisena työnä, Juhila 2006).

Onnistunut ammatillinen sosialisaatio vahvistaa luonnolliseen ymmärtämiseen perustuvaa paneutumista asiakkaiden tilanteisiin. Kyky paneutua kohtaa kuitenkin rakenteellisia uhkia, jotka liittyvät palvelujärjestelmän ja organisaatioiden tarpeisiin sekä sosiaaliteknologiseen tiedon käyttöön. Sosiaalityöntekijä on esimerkiksi lääkäriin verrattuna suhteellisen heikossa asemassa ajatellen tutkimustiedon, kliinisen kokemuksen ja asiakkaiden toiveiden itsenäistä yhdistämistä (laajasti ymmärretty näyttöön perustuva käytäntö, Pohjola 2012). Näyttöön perustuvan käytännön ajatuksena on, että ammattilainen voi valita käypähoito-suositusten valikoimasta hoidon tai terapian, jota diagnosoidun vaivan parantaminen vaatisi. Yhteiskunnallisen auttamisen ja kontrollin välimaastossa toimivilla sosiaalityöntekijöillä on harvoin käytettävissään runsaasti resursseja. Sosiaalityöllä ei ole kattavaa välineiden valikoimaa, vaan pikemminkin harvoja palveluja ja siten tilausta yksinkertaisille asiakkaiden luokitteluille. Arkiymmärrykseen perustuvaa ja siten pitkälti vaistonvaraista paneutumista tapaukseen on myös vaikea puolustaa, jos toimintaympäristössä korostetaan tieteellisesti luotettavaa empiiristä tietoa asiakkaan ongelmista ja resursseista. (Raven \& Garz 2012, 573.)

Arkisen luonnollisessa ja professionaalisessa tapauksen ymmärtämisessä käytetään julkilausumatonta, asiayhteydestä pääteltävissä olevaa tietoa kielenkäytön säännöistä ja normeista ("hiljainen tieto”). Tieteellisessäkin ymmärtämisessä nojataan tietoon kielenkäytön säännöistä ja normeista, mutta erotuksena edellisiin säännöt ja niiden noudattaminen eksplikoidaan eli ne tehdään mahdollisimman näkyviksi. Professionaalinen tapauksen (rakenteen) selvittäminen on osa ammatillista käytäntöä. Työssä tehdään käytännön valintoja, eikä asiakkaiden toiminnallisia vaihtoehtoja ole mahdollista eritellä ilman aikapaineita. Ammatillinen ymmärtäminen on siten käytännöllistä, pikakirjoituksenomaisen lyhennettyä tapauksen selvittämistä, joka tapahtuu automaattisesti ja tavallisesti ilman tapauksen rakenteen kä- 
sitettä. (Emt..) Riittää, että tapaus on käytännöllisesti katsoen samanlainen tai erilainen kuin jokin toinen tapaus, etenkin silloin, kun arvioidaan miten asiakas voisi hyötyä yhdestä tai muutamasta tarjolla olevasta palvelusta.

Rekonstruoivassa tutkimuksessa, jossa elämänkäytännön dokumentoituja ilmauksia tulkitaan vapaana käytännön pakoista, ihmisten toiminnan ja ilmaisujen merkityksiä koskevien oletusten uskottavuudelle asetetaan korkeammat vaatimukset kuin arkikäytännöissä ja professionaalisessa toiminnassa. Oletuksia ei määritellä tilannekohtaisia tarpeita vastaavalla uskottavuudella, vaan ymmärtämisen pitää olla metodisesti hallittua. Tavoitteena on löytää sekvenssianalyyttisen tulkinnan kautta tapauksen rakenne. Näin voidaan saada yleispätevää tietoa tapauksen rakenteesta. Objektiivisen merkitysrakenteen selvittäminen perustuu sääntöihin. Tutkimus selittää eritellysti ja järjestelmällisesti, miten ilmaus on tuotettu säännön avulla.

\section{OBJEKTIIVISEN HERMENEUTIIKAN JA KÄYTÄNNÖN SOSIAALITYÖN YHDISTÄMISEN MAHDOLLISUUKSIA}

Objektiivisen hermeneuttista tutkimusta ja professionaalista selvittämistä yhdistää tapauksen kokonaisvaltainen erittely. Tästä syystä metodinen tapausten rekonstruoiminen ja sitä koskeva metodologia voi toimia näkökulmana, joka tukee professionaalista ymmärtämistä. Koska tutkimus ja sosiaalityön käytäntö edustavat kuitenkin erilaisia käytäntöjä (niillä on eri säännöt), ei tapauksen tutkimuksellista rekonstruointia voi siirtää suoraan ja yleisesti käytäntöön. Tutkimuksellinen rekonst- ruktio ei voi korvata professionaalista ymmärtämistä. Objektiivisen hermeneutiikan hyödyt tulee nähdä välillisempinä. $\mathrm{Ne}$ vaativat toteutuakseen erityisiä järjestelyjä. Soveltamisen paikkoja voivat sosiaalityön opinnot, työnohjaus ja tutkimusta ja käytäntöä yhdistävät erityiset organisatoriset järjestelyt (kuten yliopistolliset sosiaalikeskukset). (Raven \& Garz 2012.) Työnohjauksessa tai ns. välittäjäorganisaatioissa tehty tapauksen rekonstruktio voisi auttaa sosiaalityöntekijöitä tai moniammatillista tiimiä löytämään uusia näkökulmia ja etenemisen reittejä haastavissa asiakastilanteissa. (Emt., 573.)

Tapauksen rekonstruktiossa pyritään pääsemään tapauksen "juuriin asti", ratkaisemaan tapauksen "arvoitus". Tämä tapahtuu selvittämällä, miten tapaus etenee sille ominaisen logiikan mukaisesti ja avaamalla näin tapaukselle ominaista rakennetta. Tapauksen jokin piirre, kuten "oireyhtymä" (mielenterveyden ongelma, krooninen kipu tai korostunut persoonallisuuden piirre) voidaan näin sijoittaa tapauksen rakennenäkökulmasta tapauksen syvempään tai laajempaan dynamiikkaan. Erittelyn tulee osoittaa, kuinka käytännön elämäntilanne todellisuudessa toimii, toistaa itseään ja muuntuu - erotuksena toimijan omaan käsitykseen tai esitykseen - ja kuinka se voisi toimia, mikäli tehtäisiin mahdollisuuksien rajoissa olevia päätöksiä. Erittelyn varassa voidaan näin perustella uudenlaisia toimenpiteitä tai puuttumista tilanteeseen. (Raven \& Garz 2012; Kraimer 2015, 74-77.) Samalla rekonstruoiva tutkimus voi laajentaa myös palvelujen kehittämiseen tähtäävää sosiaalityön tiedollista näköalaa esimerkiksi palvelumuotoilun tavoin. 


\section{KIRJALlisuUs}

Alasuutari, Pertti (2011) Laadullinen tutkimus 2.0. Tampere:Vastapaino.

Chomsky, Noam (1965) Aspects of the Theory of Syntax. Cambridge, MA: MIT Press. https://doi.org/10.21236/ AD0616323

Garz, Detlef, Raven, Uwe (2015) Theorie der Lebenspraxis. Einführung in das Werk Ulrich Oevermanns. Wiesbaden: Springer VS. https://doi.org/10.1007/978-3658-07308-4

Garz, Detlef \& Raven, Uwe (2017) Objektive Hermeneutik als rekonstruktive Forschungsmethodik in den Sozialund Verhaltenswissenschaften. Teoksessa Günther Mey \& Katja Mruck (toim.) Handbuch Qualitative Forschung in der Psychologie. Wiesbaden: Springer Reference Psychologie, 1-25. https://doi. org/10.1007/978-3-658-18387-5_60-1

Goffman, Erving (1956) The Presentation of Self in Everyday Life. Edinburgh: University of Edinburgh.

Jansen, Axel (2006) Die objektive Hermeneutik als Instrument der historischen Fallrekonstruktion: Analyse eines Briefes von Anne Morgan. Traverse: Zeitschrift für Geschichte/Revue d'histoire, 2. http://dx.doi.org/10.5169/seals-30329 Luettu 19.11.2010.

Jokinen Arja \& Juhila, Kirsi \& Suoninen, Eero (1999) Diskurssianalyysi liikkeessä. Vuorovaikutus, toimijuus ja kulttuuri empiirisen tutkimuksen haasteina. Tampere:Vastapaino.

Juhila, Kirsi (2006) Sosiaalityöntekijöinä ja asiakkaina. Sosiaalityön yhteiskunnalliset tehtävät ja paikat. Tampere:Vastapaino.

Kraimer, Klaus (2015) Fallrekonstruktion. Teoksessa Regina Rätz \& Bettina Völter (toim.) Wörterbuch Rekonstruktive Soziale Arbeit. Europe: Verlag Barbara Budrich, 74-77.

Koring, Bernhard (1997) Das TheoriePraxis-Verhältnis in Erziehungswissenschaft und Bildungstheorie. Donauwörth:Verlag Ludwig Auer.

Laine, Markus \& Bamberg Jarkko \& Jokinen Pekka (2007) Tapaustutkimuksen käytäntö ja teoria. Teoksessa Markus Laine, Jarkko Bamberg \& Pekka Jokinen (toim.) Tapaustutkimuksen taito. Helsinki: Gaudeamus, 9-38.

Lindholm, Camilla \& Stevanovic, Melisa, \& Peräkylä, Anssi (2016) Johdanto. Teoksessa Camilla Lindholm \& Melisa Stevanovic (toim.) Keskustelunanalyysi. Kuinka tutkia sosiaalista toimintaa ja vuorovaikutusta. Tampere:Vastapaino, 9-30.

Maiwald, Kai-Olaf (2003) Are Interviews a Proper Date Base for the Analyses of Occupational Practice? Methodological Considerations and a Case Study concerning Family Mediation. Sozialersinn: Zeitschrift für hermeneutische Sozialforschung 4 (1), 151-180.

Mead, George Herbert (1934) Mind, Self and Society from the Standpoint of a Social Behaviorist (Edited by Charles W. Morris). Chicago: University of Chicago.

Niemelä, Pauli (2012) Tapauskohtaisuus sosiaalityössä. "Case Study - Case Work - Case Evaluation" -prosessimalli sosiaalityön ja sen käytännön opetuksen jäsentäjänä. Teoksessa Noora

Tuohino, Anneli Pohjola \& Mari Suonio (toim.) Sosiaalityön käytännönopetus liikkeessä. Rovaniemi: Valtakunnallinen sosiaalityön yliopistoverkosto Sosnet, 20-35.

Oevermann, Ulrich (1996) Theoretische Skizze einer revidierten Theorie professionalisierten Handelns. Teoksessa Arno Combe \& Werner Helsper (toim.) Pädagogische Professionalität. Untersuchungen zum Typus pädagogischen Handelns. Frankfurt am Main: Suhrkamp, 70-183.

Oevermann, Ulrich (2000) Die Methode der Fallrekonstruktion in der Grundlagenforschung sowie der klinischen und pädagogischen Praxis. Teoksessa Klaus Kraimer (toim.) Die Fallrekonstruktion. Sinnverstehen in der sozialwissenschaftlichen Forschung. Frankfurt am Main: Suhrkamp, 58-156.

Oevermann, Ulrich (2001) Strukturprobleme supervisorischer Praxis. Eine objektiv hermeneutische Sequenzanalyse zur Überprüfung der Professionalisierungstheorie. Frankfurt am Main: $\mathrm{Hu}-$ manities Online.

Oevermann, Ulrich (2013) Objektive Hermeneutik als Methodologie der Erfahrungswissenschaften von der sinnstrukturierten Welt. Teoksessa Philip C. 
Langer, Angela Kühner \& Panja Schweder (toim.) Reflexive Wissensproduktion. Wiesbaden: Springer VS, 69-98. https:// doi.org/10.1007/978-3-658-03112-1_5

Oevermann, Ulrich (2014) 'Get closer' ${ }^{6}-$ Bildanalyse mit den Verfahren der objektiven Hermeneutik am Beispiel einer Google Earth-Werbung. Teoksessa Klaus Kraimer (toim.) Aus Bildern lernen. Optionen einer sozialwissenschaftlichen Bild-Hermeneutik. Ibbenbüren: Klaus Münstermann Verlag, 38-75.

Oevermann, Ulrich (2016) "Krise und Routine" als analytisches Paradigma in den Sozialwissenschaften. Teoksessa Roland Becker-Lenz, Andreas Franzmann, Axel Jansen \& Matias Jung (Hrsg.) Die Methodenschule der Objektiven Hermeneutik. Eine Bestandsaufnahme. Wiesbaden: Springer VS, 43-114. https:// doi.org/10.1007/978-3-658-00768-3_2

Pohjola, Anneli (2010) Asiakas sosiaalityön subjektina. Teoksessa Merja Laitinen \& Anneli Pohjola (toim.) Asiakkuus sosiaalityössä. Helsinki: Gaudeamus, 19-74.

Pohjola, Anneli (2012) Tutkimukseen perustuva vaikuttavuus. Teoksessa Anneli Pohjola, Tarja Kemppainen \& Sanna Väyrynen (toim.) Sosiaalityön vaikuttavuus. Rovaniemi: Lapin yliopistokustannus, 19-42.

Pohjola, Anneli \& Kemppainen, Tarja \& Väyrynen, Sanna (2012) Vaikuttavuus on monta. Teoksessa Anneli Pohjola, Tarja Kemppainen \& Sanna Väyrynen (toim.) Sosiaalityön vaikuttavuus. Rovaniemi: Lapin yliopistokustannus, 347-352.

Raven, Uwe \& Garz Detlef (2012) Fälle - zur theoretischen Fundierung der Interventionspraxis professionalisierter Sozialarbeit. Neue Praxis 6/2012, 565-584.

Rostila, Ilmari (2019) The Figure of Probation as a Means of Accessing the Client's Subjectivity: An Exemplary Reconstruction of the Structural Problems of Social Work. Teoksessa Olaf Behrend, Boris Zizek \& Lalenia Zizek (toim.) Au- tonomie und Bewährung. Grundbegriffe rekonstruktiver Sozialisations- und Bildungsforschung. Wiesbaden: SpringerVS, 153-178. https://doi.org/10.1007/9783-658-15809-5_10

Searle, John R. (1971) Speech Acts. Cambridge: Cambridge University Press.

Searle, John R. (1983) Intentionality. An Essay in the Philosophy of the Mind. Cambridge: Cambridge University Press. https://doi.org/10.1017/ CBO9781139173452

Sosiaalihuoltolain soveltamisopas (2017). Sosiaali- ja terveysministeriön julkaisuja 2017:5. Helsinki: Sosiaali- ja terveysministeriö.

Särkelä,Antti (2011) Välittäminen ammattina. Tampere:Vastapaino.

Süßmann, Johannes (2016) Geschichtswissenschaften und Objektive Hermeneutik. Teoksessa Roland Becker-Lenz, Andreas Franzmann, Axel Jansen \& Matthias Jung (toim.) Die Methodenschule der Objektiven Hermeneutik. Eine Bestandsaufnahme. Wiesbaden: Springer VS, 115-140. https://doi.org/10.1007/9783-658-00768-3_3

Virtanen, Matti (2001) Fennomanian perilliset. Poliittiset traditiot ja sukupolvien dynamiikka. Hämeenlinna: SKS.

Wernet, Andreas (2014) Hermeneutics and objective Hermeneutics. Teoksessa Uwe Flick (toim.) The SAGE handbook of Qualitative Data Analysis. London: SAGE, 234-246. https://doi. org/10.4135/9781446282243.n16

Ylikoski, Anne (2013) Sosiaalityön toiminta mielenterveystyössä. Tapaustutkimus psykiatrisessa sairaalassa ja avohoidossa sekä sosiaalitoimen aikuissosiaalityössä. Sosiaalityön Pro gradu -tutkielma. Tampere:Tampereen yliopisto.

Zizek, Boris (2012) Professionalität und Postkonventionalität. Entwicklungstheoretische und soziologische Perspektiven auf professionalisiertes Handeln. Ethics in Progress Quarterly, 3 (1), 97-110. 